\title{
RADIATION PROTECTION INFORMATION COMPONENT OF THE POPULATION IN THE NPP SURVEILLANCE ZONE
}

Prylypko V.A., Ozerova Yu.Yu., Kratyk P.F., Shevchenko K.K., Bondarenko I.V., Morozova M. N.

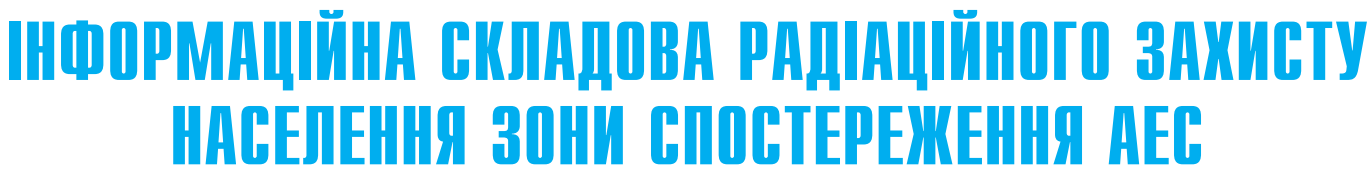

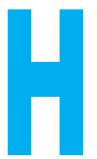

1ПРИЛИПКО В.А., 1ОЗЕРОВА Ю.Ю., 2КРАТИК П.Ф., 1 ШЕВЧЕНКО К.К., 'БОНДАРЕНКО І.В.,

1 МОРОЗОВА М.M.

1 Ду «Національний науковий центр радіаційної медицини Національної академії медичних наук України», м. Київ 2ВП «Рівненська АЕС», М. Кузнецовськ

УДК 614.876:351.862.21:621.311.25 Ключові слова: зона спостереження, інформаційне забезпечення, радіаційний захист, контент-аналіз публікацій. аселення, яке проживає поблизу атомних електростанцій (AEC), потребує особливої програми соціальної та інформаційно-психологічної безпеки. Адекватне інформування населення про ризики, що пов'язані з проживанням у зоні спостереження (ЗС) AEC; створення умов для мінімізації наслідків різних за складністю надзвичайних ситуацій (HC) $€$ запорукою безпеки життєдіяльності громади. Роль інформаційної політики при розбудові об'єктів критичної інфраструктури, зокрема атомних електростанцій, $€$ провідною [1-4]. Дослідження інформаційного забезпечення та інформаційних потреб населення, яке проживає у ЗС АEC залишається актуальною проблемою і потребує моніторин- гового дослідження та вимірювання багатьох складових, які впливають на стан безпеки життєдіяльності та якості життя загалом. Результати таких досліджень дають можливість вчасно реагувати на зміни настроїв та потреб населення i, відповідно, формувати інформаційну політику у конкретних соціальних умовах. У країнах Європейського Союзу (ЄС) досліджуються проблеми, що пов'язані з ризиком проживання у 10-кілометровій зоні [5], моніторинг ставлення громадськості до діяльності АЕС [6]. У Російській Федерації та Бєларусі проводяться моніторингові дослідження з розвитку та безпеки ядерної енергетики $[3,7]$

Соціологічні та аналітичні дослідження щодо розвитку
ИНФОРМАЦИОННАЯ СОСТАВЛЯЮЩАЯ

РАДИАЦИОННОЙ ЗАЩИТЫ НАСЕЛЕНИЯ ЗОНЫ НАБЛЮДЕНИЯ АЭС

1 Прилипко В.А., 1 Озерова Ю.Ю., 2 Кратик П.Ф., 1 Шевченко К.К., ${ }^{1}$ Бондаренко И.В.,

1 Морозова М.М.

1 Гу «Национальный научный центр радиационной медицины Национальной академии медицинских наук Украины», г. Киев

2ПП «Ровенская АЭС», г. Кузнецовск

Целью исследования было оценить состояние информационного обеспечения населения зоны наблюдения АЭС о последствиях деятельности

АЭС для окружающей среды и его соответствие существующим информационным потребностям населения, проживающего вблизи объектов критической инфраструктуры.

Материалы и методы. Исследование проводилось в зоне наблюдения (ЗН) Ровенской АЭС по нескольким направлениям: проведение контентанализа в отдельных изданиях прессы, которые распространяются на этой территории; проведение социологического опроса взрослого населения в ЗН РАЭС относительно информационных потребностей. Контент-анализ применялся для выявления особенностей информационного потока в 9 печатных изданиях СМИ и 2 Интернет-сайтах. Были проанализированы 978 статей по разработанному классификатору за период с января 2013 г. по август 2015 г. включительно. Проведен социологический опрос относительно осведомленности населения о последствиях деятельности АЭС, доверия к источникам информации и информационных потребностей среди 220 человек в ЗН РАЭС, где ошибка выборки составляет 6,7\%.
Результаты. Контент-анализ выбранных СМИ показал, что для всех изданий, кроме ведомственной «Энергии», тема, связанная с деятельностью РАЭС не является актуальной и интересной для журналистов. Среди информационного потока превалируют короткие информационные сообщения о деятельности РАЭС, чаще всего предоставленные Информационным центром (ИЦ) РАЭС.

Преобладают публикации имиджевого характера с нейтральной или положительной окраской. Органь власти не используют свои возможности для распространения полезной для населения информации и не инициируют обсуждение острых вопросов экологического характера и субвенций.

Информационное поле последствий деятельности АЭС формируется под мощным влиянием ИЦ РАЭС, которое направлено на создание положительного имиджа, но не отражает всех существующих информационных потребностей общества. Опрос населения показывает, что актуальной остается потребность в информации о состоянии радиационного фона $(77,6 \%)$, о влиянии деятельности АЭС на окружающую среду $(77,2 \%)$, подробная информация об условиях хранения и вывоза радиоактивных отходов $(45,2 \%)$ и проектов строительства новых реакторов (33,3\%). Информационная стратегия в ЗН АЭС требует пересмотра с учетом уровня грамотности по радиационно-гигиеническим вопросам и степени риска проживания у объекта ядерного цикла, состояния социальной активности и готовности принимать ту или иную информацию, установок на сохранение здоровья, наработок журналистов, освещающих 4 С

Ключевые слова: зона наблюдения, информационное обеспечение, радиационная защита, контент-анализ публикаций.

(С Прилипко В.А., Озерова Ю.Ю., Кратик П.Ф., Шевченко К.К., Бондаренко І.В., Морозова М.М. СТАТТЯ, 2016. 
ядерної енергетики України проводяться у Центрі ім. Розумкова [8] та в Інституті соціології НАНУ [2].

Метою дослідження було оцінити стан інформаційного забезпечення населення 3С щодо наслідків діяльності АЕC для довкілля та його відповідність існуючим інформаційним потребам населення, що мешкає поряд з об'єктами критичної інфраструктури.

Матеріали і методи. Дослідження проводилося у ЗС Рівненської AEC (PAEC) за декількома напрямками:

$\square$ проведення контент-аналізу в окремих виданнях преси, яка розповсюджується у ЗС PAEC, та аналіз інформаційної наповненості офіційних сайтів міських і районних рад та державних адміністрацій щодо діяльності AEC і рекомендацій на випадок надзвичайної ситуації;

口 проведення соціологічного опитування дорослого населення у ЗС РАЕС щодо інформаційних потреб.

Контент-аналіз у даному дослідженні застосовувався як допоміжний метод для виявлення особливостей інформаційного потоку у друкованих та Інтернет-виданнях засобів масової інформації (ЗМІ), які розповсюджуються у 3С РАЕС [910]. Аналіз матеріалів 3MI проводився за такими параметрами: засновник, формат, тематика, періодичність виходу, кількість сторінок, загальнотижневий наклад. Було відібрано 9 друкованих видань обласних, районних та місцевих $3 \mathrm{MI}$ та 2 Інтернет-сайтів. Зокрема, це «Рівне вечірнє», «Вісті Рівненщини», «Рівне-ракурс», «Волинь», «Новини Волині», «ОГО», «Віче-інформ», «Вісник і К», «Волинська газета», «Енергія», «4bloka». Були складені класифікатор та інструкція для дослідників первинної інформації.

До класифікатора входили категорії, за якими аналізувалися статті: дата виходу, назва статті, авторство, розмір статті, короткий опис, основна тема, форма подання, інформаційна оцінка, характер матеріалу, наявність зображення, відповідність зображення, категорія матеріалу. Загалом було проаналізовано 978 статей за період з січня 2013 по серпень 2015 року включно.

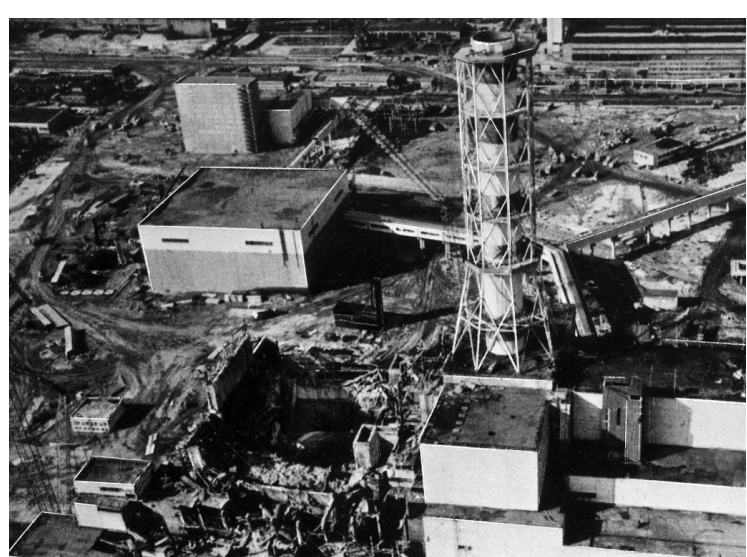

ПРОБЛЕМИ ЧОРНОБИЛЯ

До соціологічної анкети для дорослого населення входили такі блоки питань: рівень поінформованості про наслідки діяльності AEC для довкілля, стан довіри до різних джерел інформації, радіаційне забруднення води та продуктів харчування як наслідок Чорнобильської аварії; оцінка ефективності інформування населення та інформаційні потреби міського і сільського населення ЗС АЕC. При опитуванні дорослого населення застосовано безповторний ймовірнісний відбір. Вибіркова сукупність опитаних серед дорослого населення ЗС РАЕС становила 220 осіб з похибкою вибірки 6,7\%.

Результати дослідження та їх обговорення. Аналіз інформаційної наповненості офіційних сайтів міських та районних рад та державних адміністрацій ЗС РАЕС засвідчив повну відсутність повідомлень чи пам'яток для населення рекомендаційного характеру на випадок надзвичайної ситуації та повідомлень щодо отримання і використання субвенцій.

Серед проаналізованих друкованих ЗМІ потенційно найпродуктивнішою у донесенні інформації до населення $\epsilon$ газета «Волинь», яка має най- більший загальнотижневий тираж (200 000 екземплярів). Проте у ній знайдено найменшу кількість друків щодо визначеної тематики. Найменш розповсюдженою є відомча газета «Енергія» (2 000 екземплярів на тиждень), але на їі сторінках було знайдено найбільшу кількість публікацій (529), що можуть бути корисними для населення. Слід зазначити, що усі газети мають свої сайти та доступні в Інтернет-просторі, а «Енергія» розміщена на декількох сайтах: офіційному Рівненської AЕС та інформаційному сайті М. Кузнецовська «4bloka». Проте переглядає сайт інформаційного агентства «Новини Волині», інформаційного порталу «4bloka» та Інтернет-сайтів газет специфічна аудиторія: це частка населення, яка має комп'ютер, Інтернет, звикла більше користуватися електронними виданнями, ніж друкованими, віком від 18 до 35 років.

Аналіз статей проводився за 10 темами (табл. 1).

Перше місце за рейтингом публікацій посідають, зазвичай, офіційні, короткі, без аналізу друки (повідомлення) про діяльність РAEC.

Друге місце - об'ємна та різноманітна тема щодо еколо-

Таблиця 1

Розподіл кількості статей за тематичним спрямуванням у друкованих та Інтернет-виданнях

\begin{tabular}{|l|c|}
\hline \multicolumn{1}{|c|}{ Тематика статті } & Загалом \\
\hline Експлуатаційна діяльність РАЕС & 599 \\
\hline Надзвичайні ситуації на РАЕС & 8 \\
\hline Екологічний стан, екологічний контроль та безпека РАЕС & 131 \\
\hline Іміджеві повідомлення, спонсорська допомога & 130 \\
\hline Рекомендації для населення у ЗС та на випадок НС & 11 \\
\hline Здоров'я населення у зоні спостереження та на РЗТ & 0 \\
\hline Субвенції від АЕС та їх використання & 16 \\
\hline Юридичний та правовий аспект соціального захисту населення & 15 \\
\hline Розвиток ядерної енергетики & 24 \\
\hline Інше & 48 \\
\hline
\end{tabular}


статті, де висвітлюється спонсорська чи благодійна допомога, участь співробітників РАEС у будь-яких позитивних заходах, які мають суспільне визнання.

Тему розвитку ядерної енергетики розкриває на своїх сторінках газета «Енергія» в аналітичних та інформаційно-аналітичних статтях (20 публікацій). В інших виданнях цій темі не приділялося належної уваги за досліджуваний період.

Тема субвенцій та їх використання обговорювалась у газетах «Енергія» (8 публікацій), «Рівне вечірнє» (3 публікації), на сайті «Новини Волині» (2 публікації) та по одній публікації у виданнях «Віче-інформ», «Волинська газета», «4bloka». На шпальтах офіційної газети «Вісті Рівненщини» ані повідомлення, ані обговорення субсидій, що надходять як ком-

Таблиця 2

Розподіл відповідей респондентів за ступенем довіри до інформації за місцем проживання (\%)

\begin{tabular}{|c|c|c|c|c|c|c|}
\hline \multirow{3}{*}{ Джерело інформації } & \multicolumn{6}{|c|}{ Група населення } \\
\hline & \multicolumn{3}{|c|}{ міське } & \multicolumn{3}{|c|}{ сільське } \\
\hline & 1 & 2 & 3 & 1 & 2 & 3 \\
\hline Телебачення & 26,3 & 59,9 & 13,8 & 20,6 & 69,1 & 10,3 \\
\hline Радіо & 27,6 & 59,2 & 13,2 & 27,9 & 61,8 & 10,3 \\
\hline Преса загальнодержавна & 36,8 & 55,3 & 7,9 & 27,9 & 58,8 & 13,2 \\
\hline Преса місцева & 32,2 & 53,9 & 13,8 & 29,4 & 60,3 & 10,3 \\
\hline Освітні заклади (дитсадки, школи) & 34,2 & 49,3 & 16,4 & 26,5 & 52,9 & 20,6 \\
\hline Місце роботи & 17,1 & 52,6 & 30,3 & 20,6 & 39,7 & 39,7 \\
\hline Місцева адміністрація & 34,2 & 47,4 & 18,4 & 29,4 & 47,1 & 23,5 \\
\hline $\begin{array}{l}\text { Лікувальні медичні заклади } \\
\text { (поліклініка, лікарня, фельдшерсько- } \\
\text { акушерські пункти) }\end{array}$ & 26,3 & 50,7 & 23,0 & 23,5 & 51,5 & 25,0 \\
\hline Санітарно-епідеміологічна станція & 25,0 & 56,6 & 18,4 & 25,0 & 63,2 & 11,8 \\
\hline Сусіди, друзі, знайомі & 30,9 & 54,6 & 14,5 & 25,0 & 61,8 & 13,2 \\
\hline Фахівці з проблеми & 14,5 & 52,0 & 33,6 & 26,5 & 50,0 & 23,5 \\
\hline Інше & 32,1 & 52,8 & 15,1 & 53,8 & 38,5 & 7,7 \\
\hline
\end{tabular}

Примітка: шкала вимірювання від 1 до 3,

де 1 - не довіряю, 2 - деякою мірою, 3 - довіряю.

Оцінка населенням ефективності інформування

Таблиця 3 що пов'язане з проживанням у зоні спостереження PAEC, співробітниками установ та організацій $(\mathrm{M} \pm \mathrm{m})$

\begin{tabular}{|l|c|c|c|}
\hline \multirow{2}{*}{\multicolumn{1}{|c|}{ Організації }} & \multicolumn{3}{c|}{ Група населення } \\
\cline { 2 - 4 } & міське & сільське & загалом \\
\hline Співробітники АЕС & $2,56 \pm 0,11$ & $2,70 \pm 0,17$ & $2,61 \pm 0,10$ \\
\hline Органи місцевої адміністрації & $2,24 \pm 0,10$ & $2,60 \pm 0,17$ & $2,35 \pm 0,09$ \\
\hline Медичні установи & $2,47 \pm 0,11$ & $2,69 \pm 0,16$ & $2,54 \pm 0,09$ \\
\hline Екологічні товариства & $2,28 \pm 0,10$ & $2,25 \pm 0,17$ & $2,27 \pm 0,09$ \\
\hline Освітні заклади & $2,26 \pm 0,10$ & $2,75 \pm 0,17$ & $2,42 \pm 0,09$ \\
\hline
\end{tabular}

Примітка: шкала вимірювання від 1 до 5,

де 1 - негативна, 5 - позитивна. пенсація для ЗС РАEC, не було. Тобто у середньому протягом року близько 6 публікацій 3 теми, яка $€$ актуальною для населення.

Тему юридичного та правового соціального захисту загалом висвітлено у 15 публікаціях, але жодна 3 них не пов'язана з АEC.

Публікації, спрямовані безпосередньо на пересічне населення, в яких надавалась би інформація рекомендаційного характеру, що робити на випадок HC на AEC, практично відсутні. Питання безпеки населення розглядаються в окремих статтях, де повідомляється про протипожежні чи штабні навчання на AEC, в яких ані населення, ані місцева адміністрація участі не беруть.

Про надзвичайні ситуації на РАЕС було 8 повідомлень у газетах «Рівне вечірнє», «ОГО», «Енергія» та «4bloka».

Теми щодо здоров'я населення у зоні спостереження AEC та на РЗТ не висвітлювало жодне видання за досліджуваний період, хоча саме вона $€$ найбільш затребуваною населенням.

Більшість друків усіх тематичних спрямувань надходить від Інформаційного центру PAEC, зокрема 30,1\% - пряме авторство центру і 32,2 \% опосередковане, без визначення авторства. Публікації фахівців були розміщені у газетах «Вісті Рівненщини», «Рівнеракурс», «Новини Волині», «Рівне вечірнє». 21,6\% публікацій в «Енергії» належать саме фахівцям. Проте не все населення зони спостереження має до неї доступ.

За формою подання матеріалів лідирує коротке повідомлення - 69,6\%, на другому місці - журналістська стаття $(25,3 \%)$, на третьому - статтяінтерв'ю $(4,7 \%)$.

За інформаційним забарвленням більшість статей має нейтральний характер, крім публікацій в «ОГО», «Вісник і К» та сайту «4bloka», де превалюють позитивно забарвлені статті.

94,0\% матеріалу, що аналізувався, характеризуються виключно як інформаційні і мають мінімальне змістовне навантаження. Краще запам'ятовуються та змушують людину мислити інформаційно-аналітичні $(4,9 \%)$ та аналітичні матеріали 
RADIATION PROTECTION INFORMATION COMPONENT OF THE POPULATION IN THE NPP SURVEILLANCE ZONE 1 Prylypko V.A., 1 Ozerova Yu.Yu., ${ }^{2}$ Kratyk P.F., 1Shevchenko K.K., 1 Bondarenko I.V., 1 Morozova M.N. 1 State Institution "National Research Center for Radiation Medicine of the National Academy of Medical Sciences of Ukraine", Kyiv

2SE "Rivne NPP", Kuznetsovsk

Objective. We assessed a state of the information of the population in the NPP surveillance zone on the consequences of nuclear power plant activity for the environment and its compliance with the existing information needs of the population residing near the objects of critical infrastructure.

Materials and methods. The study was performed in the surveillance zone of the Rivne NPP in several directions: performance of the content analysis in separate editions of the press that are distributing at this territory; sociological survey of the adults on the information needs in the Rivne AP. We used the content analysis for the identification of the features of the information flow in 9 editions and 2 internet sites. 978 articles were analyzed according to the developed classifier for the period from January 2013 to August 2015. We have performed the sociological survey on the public awareness of the consequences of the NPP activity, the credibility of information sources and information needs among 220 persons in the surveillance zone of the Rivne NPP where a sampling error is $6.7 \%$.
Results. Content analysis of the selected media showed that a theme, connected with the activity of the Rivne NPP, was not topical and interesting for the journalists of all editions except specialized "Energy". Short news reports on the activities of the Rivne NPP, often provided by the NPP Information Centre (IC), prevail among the information flow. Publications of image character with neutral or positive tone predominate. The authorities do not use their opportunities to disseminate the information useful for the population and do not initiate the discussions on the critical environmental issues and subventions. Information field on the consequences of the NPP activity is forming under the powerful influence of IC NPP, which is directed on the creation of a positive image, but does not reflect all existing information needs of the community. The survey of the population indicates that there is a need of the information on the status of the background radiation (77.6\%), the impact of the NPP on the environment (77.2\%), detailed information on the conditions of storage and export of radioactive waste (45.2\%) and a new reactor design solution (33.3\%). Information nuclear strategy in the NPP surveillance zone requires a revision, taking into account a literacy in the radiation-hygienic issues and a risk degree of the residence near the nuclear cycle facility, a state of social activity and a readiness to accept one or the other information, guidelines for the health preservation, developments of the journalists who cover the emergencies.

Keywords: surveillance area, information support, radiation protection, content analysis of publications.
$(1,1 \%)$, але їх мінімальна кількість.

Наявність зображення у статтях $(61,3 \%)$ робить статтю більш привабливою. Відповідність зображення тексту свідчить про професіоналізм видавця. Вони складають 72,7\% усіх друків.

Дані контент-аналізу матеріалів засобів масової інформації були співставлені з даними опитування населення щодо їх запитів. Ступінь довіри до джерел інформації можна визначити як середній. Нині ЗМІ користуються довірою деякою мірою (табл. 2). Позитивним $є$ те, що найвищий рівень довіри у населення мають фахівці 3 проблеми (30,5\%) та інформація, яка надходить за місцем роботи $(33,2 \%)$. Лише п'ята частина населення довіряє інформації, що надходить від місцевої адміністрації, лікувальномедичних закладів та освітян. Це свідчення втрати довіри до будь-яких державних інституцій як реакція на вирішення, а скоріше, невирішення таких проблем, як подолання наслідків катастрофи на ЧАЕС.

Дані опитування свідчать, що нині довіра до інформації від різних інституцій близька до нейтральної (табл. 3). Оцінки сільського населення дещо вищі, ніж міського. Загалом населення оцінює інформацію, яка надходить від органів місцевої адміністрації, екологічних товариств та фахівців освітніх закладів, нижче середнього. Оцінка ефективності інформування співробітниками AEC та медичними установами оцінена близько до нейтральної. Причини такої реакції населення вимагають додаткового дослідження.

у населення постійно залишається актуальною потреба в інформації про стан радіаційного фону $(77,6 \%)$ та про вплив діяльності AEC на довкілля (77,2\%) (табл. 4). Детальна інформація, що пов'язана 3 діяльністю AEC (умови зберігання та вивезення радіоактивних відходів), турбує вже 45,2\% опитаних, а яке буде проектне рішення нового реактора -

Розподіл тематики інформації, яку хотіло б отримувати населення у зв'язку з проживанням у зоні спостереження AEC (\%)

\begin{tabular}{|l|c|c|c|}
\hline \multirow{2}{*}{ Тема } & \multicolumn{3}{c|}{ Група населення } \\
\cline { 2 - 4 } & міське & сільське & загалом \\
\hline Стан радіаційного фону & 77,5 & 77,9 & 77,6 \\
\hline $\begin{array}{l}\text { Умови зберігання та вивезення } \\
\text { радіоактивних відходів }\end{array}$ & 44,4 & 47,1 & 45,2 \\
\hline $\begin{array}{l}\text { Вплив діяльності АЕС на довкілля } \\
\text { (вода, повітря, ґрунт, продукти) }\end{array}$ & 73,5 & 85,3 & 77,2 \\
\hline Проектні рішення нових реакторів & 31,8 & 36,8 & 33,3 \\
\hline Інше & 3,3 & 5,9 & 4,1 \\
\hline 2016 & \multicolumn{3}{|l}{} \\
\hline
\end{tabular}

лише 33,3\%. Тобто пересічне населення, не довіряючи інформації, яка надходить, не готове заглиблюватися у технічні нюанси та проблеми.

\section{Висновки}

Інформаційне поле зони спостереження щодо наслідків діяльності AEC на природне середовище формується під потужним впливом Інформаційного центру PAEC, яке спрямоване переважно на створення позитивного іміджу, але не віддзеркалює існуючих інформаційних потреб у суспільстві.

Аналіз інформаційного забезпечення показав, що майже для усіх видань, крім відомчої «Енергії», тема, що пов'язана з діяльністю РАEС, не є актуальною та цікавою для журналістів. Серед інформаційного потоку у друкованих $3 \mathrm{Ml}$ пре-

Таблиця 4 
валюють короткі інформаційні повідомлення про діяльність PAEC, найчастіше надані Інформаційним центром РАЕС. Переважають публікації іміджевого характеру з нейтральним чи позитивним забарвленням.

Обласні державні адміністрації, що $€$ співзасновниками окремих $3 \mathrm{MI}$, не використовують свої можливості для розповсюдження корисної для населення 3С AEC інформації та не ініціюють обговорення питань ані екологічного характеру, ані отримання і розподілу субвенцій, а також не залучають до співпраці фахівців медичних установ та освітніх закладів.

Інформаційна стратегія зон спостереження AEC вимагає оптимізації 3 урахуванням рівня освіченості з радіаційногігієнічних знань та ступеня ризику проживання біля об'єкта ядерного циклу, стану соціальної активності та готовності сприймати ту чи іншу інформацію, настанов на збереження здоров'я, напрацювань журналістів, які висвітлюють НС

Адекватне усвідомлення ризиків проживання у ЗС AEC за допомогою відкритої та доступної інформації про будь-які нюанси діяльності AEC та її наслідки обов'язково знайдуть позитивний відгук серед пересічного населення, що сприятиме зниженню рівня соціально-психологічної напруги серед населення та надасть відчуття безпеки.

ЛІТЕРАТУРА

1. Комплекс профілактичних заходів, спрямованих на збереження здоров'я населення зони гарантованого добровільного відселення : метод. рек. / В.А. Прилипко, О.О. Петриченко, А.А. Мишковська та ін. - К., 2013. - 30 c.

2. Саєнко Ю.І. Соціальнопсихологічне ставлення населення України до ядерних і радіаційних технологій // Ядерний енергетичний комплекс і громадськість України: шляхи до порозуміння : матер. засідання круглого столу, 02.12.2009. - Режим доступу : http://www.ukrns.odessa.net/pu blic.htm.

3. Архангельская Г.В. Оптимизация информационной работы по проблемам радиационной гигиены с населением, проживающим на тер- ритории радиоактивного загрязнения / Г.В. Архангельская, И.А. Зыкова // Радиационная гигиена. - 2008. - Т. 3, № 1. - C. 4-11.

4. Трафимчик 3.И. Опыт информационной работы с населением и общественностью по вопросам развития ядерной энергетики / З.И Трафимчик, Н.Я. Борисевич, О.В. Соболев // Энергетическая стратегия. - 2011. - № 1 (19). - C. 35-38. 5. Gordelier S. Allemagne, Grande Bretagne: Le risque de leucйmie croot a proximitй de centrales nuclŭaires [Електронний ресурс] / S. Gordelier // I'Universitŭ de Mayence en collaboration avec le registre allemand des cancers infantiles, 15.12.2011. - Mode of success : http://www.lexpress.fr/actualite/sciences/sante/habiterpres-d-une-centrale-nucleairefavoriserait-la-leucemie-chez-Ienfant 1070801.htm

6 . Kovacs P. L'energie nucleaire et I'opiion publique / P. Kovacs, S. Gordelier // Faits et opinions, AEN Infos 2009. - № 27.1

7. Хурс М.Н. Динамика общественного мнения о строительстве АЭС в Республике Беларусь / М.Н. Хурс // Энергетическая стратегия. - 2011 - № 3 (21). - С. 31-35.

8. Недашківська Д. Громадська думка про стан і розвиток ядерної енергетики України / Д. Недашківська, В. Шовкун // Національна без пека і оборона. - 2008. - № 3. - C. 52-60.

9. Галян О.І. Експериментальна психологія : навч. посіб. / О.І. Галян, І.М. Галян. - К. : Академвидав, 2012. - 400 с.

10. Семенова А.В. Контентанализ СМИ: проблемы и опыт применения / А.В. Семенова, М.В. Корсунская ; под ред. B.А. Мансурова. - М.

Институт социологии РАН, 2010. - 324 C.

\section{REFERENCES}

1. Prylypko V.A., Petrychenko O.O., Myshkovska A.A., OzerovaYu.Yu., Morozova M.M., Bondarenko Y.V., Pustovit I.M. Kompleks profilaktychnykh zakhodiv, spryamovanykh na zberezhennia zdorovia naselennia zony harantovanoho dobrovilnoho vidselennia : metodychni rekomendatsii [Complex of the Preventive Measures Directed on the Preservation of the Health of the Population in a Zone of
Guaranteed Voluntary Resettlement]. Kyiv; 2013 : 30 p. (in Ukrainian).

2. SaienkoYu.l. Sotsialnopsykholohichne stavlennia naselennia Ukrainy do yadernykh i radiatsiinykh tekhnolohii [SocialPsychological Attitude of the Population of Ukraine to Nuclear and Radiation Technologies]. In : Yadernyi enerhetychnyi kompleks i hromadskist Ukrainy: shliakhy do porozuminnia : mater. zasidannia kruhloho stolu, 02.12.09 [Nuclear Power Complex and the Public of Ukraine: Materials of the Round Table Meeting, 02.12.09]. Available at : http://www.ukrns. odessa.net/public.htm. (in Ukrainian)

3. Arkhangelskaia G.V., Zykova I.A. Radiatsionnaia gigiena. 2008 ; 3 (1) : 4-11 (in Russian).

4. Trafimchik Z.I., Borisevich N.Ya., Sobolev O.V. Energeticheskaia strategiia 2011; 1 (19) : 35-38

(in Russian)

5. Gordelier S. Allemagne Grande Bretagne: Le risque de leucйmie croot a proximitй de centrales nuclŭaires. In :

I'Universitй de Mayence en collaboration avec le registre allemand des cancers infantiles, 15.12.2011. Available at: http://www.lexpress.fr/actualite/sciences/sante/habiterpres-d-une-centrale-nucleairefavoriserait-la-leucemie-chez-Ienfant_1070801.html

6. Kovacs P., Gordelier S. La Division du development nucleaire de I'AEN, AEN Infos 2009 ; 27(1).

7. Khurs M.N. Energeticheskaia strategiia. 2011 ; 3 (21) : 31-35 (in Russian).

8. Nedashkivska D. and Shovkun V. Natsionalna bezpeka i oborona. 2008 ; $3: 52-60$ (in Ukrainian).

9. Halian O.I., Halian I.M. Eksperymentalna psykholohiia : navch. posib. [Experimental Psychology: Manual]. Kyiv : Akademvydav ; 2012 : 400 p. (in Ukrainian).i

10. Semionova A.V. , Korsunskaia M.V. ; Mansurova V.A. (ed.) Kontent-analiz SMI: problemy i opyt primeneniia [Mass Media Content-Analysis: Problems and Experience of Application]. Moscow : Institut sotsiologii RAN; 2010 : 324 p

(in Russian).

Надійшло до редакції 28.04.2016 